\title{
THE EFFECT OF HUMAN RESOURCE ACCOUNTING (HRA) ON PROFITABILITY: A STUDY OF SELECTED FIRMS QUOTED ON THE NIGERIAN STOCK EXCHANGE
}

\author{
Godwin, Adaobi Ozioma ${ }^{1}$, Udeh, Francis N. P. $(\text { PhD })^{2}$ \\ ${ }^{\prime}$ Department of Accountancy, Nnamdi Azikiwe University, Awka, Nigeria \\ ${ }^{2}$ Department of Accountancy, Nnamdi Azikiwe University, Awka, Nigeria
}

Article DOI: https://doi.org/10.36713/epra8891 DOI No: 10.36713/epra8891

\begin{abstract}
This study evaluated the effect of Human Resource Accounting on profitability: A study of selected firm's quoted on the Nigerian stock exchange. The study adopted ex-post facto research design. The population of the study was 116 firms categorized as non-financial services sector. Purposive sampling technique was used and 76 firms were considered which had secondary data information that covered a period of 10years from 2010-2020. The regression analysis/hypothesis testing was done with the aid of linear structural relations LISREL 8.80 student edition. Data were sourced from annual reports and accounts and Nigerian stock exchange fact book 2020. Findings using profitability measure showed that Staff Training and Development cost has a significant positive effect on EBTIDA but no significant positive effect on ROCE of quoted nonfinancial service firms. . Increment in number of staff has no significant positive effect on EBTIDA but has a positive significant effect on ROCE of quoted non-financial service firms. The study concluded that Human Resource Accounting affects corporate performance of non-financial service firms quoted on the Nigerian Stock Exchange. It is therefore recommended among others, that staff training and development has to be a regular program both on-the-job and off-the job tailored towards filling the identified skills and attitude gaps in the company. Also Increment in the number of staff should be encouraged as this will attract more positive effect on ROCE.
\end{abstract}

\section{INTRODUCTION}

Human resource accounting is the activity of knowing the cost invested on employees towards their recruitment, training them, payment of salaries \& other benefits paid and in return knowing their contribution to organization towards its profitability. Human Resource refers to the set of individuals who make up the workforce of an organization or a business entity. Since every organization is made up of people, acquiring their services, developing their skills and talents, motivating them to higher levels of performance and ensuring that they continue to maintain their commitment are essential to accomplishing organizational goals and objectives (Aswattappa, 2005).

An organization with abundant physical resources may sometimes fail unless it has the right people or human resources, to manage its affairs. Human Resource Accounting (HRA) has been the focus of much academic research since the late 1960's which may be attributed to the apparent increasing recognition of the importance which major stakeholders attach to socially and environmentally responsible corporate behavior within the business community (Enofe, Mgbame \& Ovie, 2013). Management Scholars have argued that the quality of human resources differentiates successful organizations from others (Robbins, 2001 cited by Omodero\&Ihendinihu, 2017). This involves the ability to attract, train, and retain quality manpower. Human resources framework has to do with training of employees. Firms has to leverage the capabilities and skills of employees by encouraging individual learning and creating a helpful environment in which knowledge can be created, 
shared and applied firms goal (Appah, Tebepah \& Soreh, 2012).

So many studies have been carried out in the area of Human Resource Accounting as it affects the profitability of firms in the developed and developing economies for decades. Studies showed that Human Resource Accounting significantly affects profitability to the best of the researchers' knowledge. For instance Amahalu, Agbionu and Obi (2017) examined the effect of human resources accounting on profitability of selected quoted telecommunication firms in Nigeria from 2010-2015 using secondary data. Results reveal that human resource accounting has a positive significant effect on ROA, ROE and ROCE at 5\% significance level. Alekhya and Lakshm (2021) result indicated that both the top line and bottom-line growth indicators have a relationship with the Human Resource Accounting. Edom, Inah, and Adanma(2015) revealed that there is a positive relationship between the indicators of human resource cost (training cost, development cost and number of staff) and the profit of the organization (Access Bank $\mathrm{Plc})$.

There is need to determine whether secondary data using a different proxy for profitability will have similar effects on firms profitability. Moreover, majority of the studies were carried out on financial sector with little or very insignificant study on nonfinancial sector to the best of the researchers' knowledge. Hence this study attempts to evaluate the effect of Human Resource Accounting on the profitability of quoted firms not categorized as financial sector on the Nigerian Stock Exchange.

The main purpose of this study is to establish the extent to which Human Resource Accounting affects Profitability of Quoted Firms in Nigeria. Specifically, the study seeks to:

1. Evaluate the effect of Staff Training \&

Development Costs on Earnings Before Taxes, Interest, Depreciation, Amortization (EBTIDA)

2. Examine the effect of Staff Training and Development Costs on return on capital employed (ROCE)

3. Determine the effect of Increment in number of staff on Earnings Before Taxes, Interest, Depreciation, Amortization(EBTIDA)

4. Access the effect of Increment in number of staff on Return on Capital Employed (ROCE).

\section{REVIEW OF RELATED LITERATURE} Concepts of Human Resource Accounting (HRA)

Human Resource Accounting is the activity of knowing the cost invested for employees towards their recruitment, training them, payment of salaries \& other benefits paid and in return knowing their contribution to organization towards it's profitability. Human resource accounting is an attempt to identify and report investments made in the human resources of an organization that are not presently accounted for under conventional accounting practice. Basically, it is an information system that tells the management what changes overtime are occurring to the human resources of the business, and of the cost and value of the human factor to the organization.

Rahaman, Hossain and Akterl (2013) gave more specific definition of HRA, which refers HRA as the process of measuring the cost incurred by business firms and other organizations to recruit, select, hire, train and develop human asset. This definition gives a view as to what expenditure on the human resources should be recognized for valuation and reporting purposes. In other words, HRA involves the measurement of economic value of people to organizations.

\section{Profitability}

Profitability is a situation in which an entity is generating a profit. It is a measure of an organization's profit relative to its expenses. It is the primary goal of all Organization. Though, profitability is an important yardstick for measuring the efficiency, the extent of profitability cannot be taken as a final proof of efficiency. According to Harward and Upton (2012), profitability is the "the ability of a given investment to earn a return from its use. However, the term 'Profitability' is not synonymous to the term 'Efficiency'. Profitability is an index of efficiency; and is regarded as a measure of efficiency and management guide to greater efficiency. It could be regarded as one of the key determinant factors that are widely used in measuring the success or failure of organizations.

\section{Measurement of Profitability}

For the purpose of this study, the following determinants (dimensions) and proxies were used:

1.Earnings Before Tax Interest Depreciation and Amortization (EBTIDA)

2.Return on Capital Employed (ROCE)

\section{EBTIDA}

EBTIDA or earnings before interest, taxes, depreciation, and amortization, is a measure of a company's overall financial performance and is used as an alternative to simple earnings or net income in some circumstances. Simply put, EBTIDA is a measure of profitability. The earnings, tax, and interest figures are found on the income statement, while the depreciation and amortization figures are normally found in the 
notes to operating profit or on the cash flow statement. EBTIDA can be used to analyze and compare profitability among companies and industries, as it eliminates the effects of financing and capital expenditures.

\section{(ii) Return on Capital Employed(ROCE)}

Return on Capital Employed (ROCE) is a financial ratio that can be used to assess a company's profitability and capital efficiency. In other words, it can help to understand how well a company is generating profits from its capital as it is put to use.Inherently, ROCE is hailed to be one of the better indicators of a company's return as it compares the profitability relative to both equity and debt. Further, it is used to compare companies of similar scale and operating within the same industry. Also, please note that companies with large cash reserves happen to include that cash as part of the capital employed in the calculation of ROCE, which is not the usual practice. The formula for ROCE can be derived by diving earnings before interest and taxes (EBIT) or net operating profit by the difference between total assets and total current liabilities, and then it is expressed in terms of percentage. Mathematically, it is represented as,

\section{Return on Capital Employed =} EBIT / (Total Assets - Total Current Liabilities)

Another formula for ROCE can be derived by dividing net operating profit by aggregate long-term liabilities and shareholder's equity. Mathematically, it is represented as,

Return on Capital Employed = EBIT / (Long Term Liabilities + Shareholder's Equity)

\section{REVIEW OF EMPIRICAL STUDY}

Many scholars have attempted researches in this area with varying findings and limitations;

Alekhya and Lakshm (2021) studied Impact of

Human Resource Accounting on Companies Profitability. The study focused on the human resource accounting system using secondary data. The study considered five industries that were implementing the Human Resource Accounting from the period of 201314 to 2018-19. The statistical tools adopted for the research work were the bivariate correlation and the result indicated that both the top line and bottom-line growth indicators have a relationship with the Human Resource Accounting. The ordinary least square method was applied and the result indicated that both the top line and bottom line indicators were significantly influenced by human resource accounting. Udeh (2021) examined the impact of Human Resource Accounting on firms value in Nigeria. The study adopted ex-post facto research design and the population of this study comprised of the 21 Deposit money banks that were listed on the Nigeria stock exchange during the period 2010 to 2015. It considered multiple regression analysis as a tool for data analysis with the aid of SPSS V. 20. Based on the findings, the researcher has come to conclusion in respect of the each hypothesis that human capital has no significant effect on earning per shares of listed firms. Sajuyigbe, Ikotun and Obi (2020) studied Human Resource Accounting and Organizational Performance: Empirical Investigation of Nigerian Banks. This study analyzed the impact of human resource capital on organizational performance with specific reference to Nigerian banks. The investigation made utilized an ex post facto research design and auxiliary data from 2010 to 2019. The study uncovered that organizational financial related execution relies on the presentation of the people that make up the organization. The investigation has indicated that workers' wages and salaries have a positive and noteworthy impact on the benefit making capacity of chose banks. This further reveals that for the chosen banks to continue to sustain and improve on their revenue generation ability in terms of profitability, there is a demand for the management to comprehend and value the contribution of its workforce towards the achievement of organizational goals. Adetoun, Oluwatobi ,Akinyemi and Abeeb (2020) studied Human Resource Accounting disclosures and financial performance: empirical evidence from manufacturing companies in Nigeria from 2015-2019.The study employed the multiple regression analysis (MRA) and findings showed that both the HR Training \& Development Cost (HRTDC) and HR Remuneration Cost (HRRC) jointly and individually have noticeable effect on the financial performance of manufacturing companies in the country, Nigeria. The study also found that financial performance is dependent upon human resource accounting. HR Training and Development Cost and Remuneration Cost have significant contributions to the financial ability of a firm. Chukwu (2018)The study investigated Human Resource Accounting and the Profitability of banks in Nigeria, 2002 to 2017. Expo facto research design and time series data were adopted for this study. Data for the study were collected from Annual Reports of First Bank of Nigeria Plc and United Bank for Africa Plc. Data collected were analyzed and tested with ordinary least square regression method (OLS) with aid of $E$ view version 9.0. The study revealed that staff salary and staff training have positive effect on bank profitability while staff development revealed inverse effect. Ezejiofor, John-Akamelu and Iyidiobi (2017) studied the appraisal of human resource accounting on 
profitability of corporate organization. This study was an attempt to determine the adoption of HRA (increase in staff salary, increment in staff and staff retirement benefits) on the profitability of corporate organizations. The findings of the study demonstrated that increase in staff salary has a positive effect on organizational profitability, also that the level of increment in staff has impact in predicting the profitability of the firm. Amahalu, Agbionu and Obi (2017) examined the effect of human resources accounting on profitability of selected quoted telecommunication firms in Nigeria from 2010-2015. Ex-post facto research design and ordinary least square analytical technique were employed. The data analysis was carried out with the aid of SPSS (23.0). Results reveal that human resource accounting has a positive significant effect on ROA, ROE and ROCE at 5\% significance level. The researcher recommends human resources as one of the strategic resources of telecommunication firms and they should imbibe the culture of training and development of employees to ensure sustainability of its competitive advantage also, the international financial reporting committee(IFRC) should incorporate an accounting standard for the valuation and disclosure of human capital values in the financial reports. Ekundayo and Odhigu(2016) studied the determinants of human capital accounting in Nigeria. Secondary data was used for the study and the data were sourced from the annual reports of 30 companies listed on the Nigerian stock exchange(NSE) fact-book as at December 2014.Pooled data research design was adopted in this study while ordinary least square regression technique was used to test the relationship between variables. The study revealed that size of the employee, welfare and training have significant impact on the human capital accounting in Nigeria. They concluded that the size of the employee would enhance the overall performance of the organization. Agbiogwu, Ihendinihu and Azubike (2016) investigated the effects of human resources cost on the profitability of banks in Nigeria from 2010 - 2014 using First Bank Nigeria, Plc and Zenith bank Nig. Plc. The study adopted content method of analysis and linear regression model to test the stated hypotheses. Findings revealed that staff cost significantly affect Earnings per share, Net profit margin, and Return on capital employed of banks. Amahalu, Obi, Okika and Abiahu(2016) studied the effect of Human resource accounting on financial performance of quoted deposit money banks in Nigeria. The specific objectives are to ascertain the effect or otherwise of staff cost on return on asset, return on equity and market-to book value of banks listed on the floor of Nigeria Stock Exchange from 2010 - 2015. Expost fact research design was used for this study.
Secondary data were sourced from the publications of NSE. Inferential statistics of the hypotheses were carried out with the aid of STATA 13 statistical software using Coefficient of correlation and ordinary least square regression analysis. Findings revealed that Human Resource Accounting has a positive and statistically significant effect on financial performance at 5\% significance level. Edom, Inah, and Adanma (2015) study was to examine the impact of human resource accounting on the profitability of Access Bank of Nigeria Plc, from 2003 to 2012.Using the ordinary least square analytical technique, secondary data from Access Bank of Nigeria Plc were obtained. Findings revealed that there is a positive relationship between the indicators of human resource cost (training cost, development cost and number of staff) and the profit of the organization (Access Bank Plc). It was also discovered that there was a significant relationship between training cost, development cost and the profit of the bank. Adebawojo, Enyi and Adebawo (2015) investigated the effect of human asset accounting on the performance of business organisations in Nigeria. The empirical study adopted ex-post facto research design, conducted on all publicly quoted 18 banks in Nigeria capital market. The instrument of data collection was questionnaire designed on a six-step Likert scale and validated through peer review with Cronbach Alpha Coefficient of 0.807 and 0.870 for human asset and organisation performance respectively. The hypotheses were tested using regression model. Results confirmed that human asset accounting significantly affects the banks performance. The study concludes that capitalising human assets would positively impact on performance of organizations and recommended its disclosure as intangible asset in the statement of financial position.

\section{METHODOLOGY}

This research work adopted the Ex-post-facto research design.

The population of the study consisted of one hundred and sixteen (116) firms not categorized as financial sector quoted on the floor of the Nigerian Stock Exchange (NSE) in the period 2010-2020 ( as at December 2020).

\section{Sample size and Sampling Procedure}

One common problem identified with prior studies especially as it pertains to the information contained in most database and records of firms especially in developing countries for which Nigeria is not an exception, is the problem of missing data which tend to be a recurring decimal (Angahar \& Malizu, 2015). With the above in mind, efforts were made in 
this study to cater for problems associated with missing data stream so that the data that were used in this study were consistent over the study period for all firms. Hence, the purposive sampling technique was however adopted in this study by first, establishing the company must be in operation throughout the study period and must have up to date accounts, appropriately filed with the Securities and Exchange Commission (SEC) throughout the study period $(2010-2020)$. The selection of the firms that were included in the sample of this study was based on the above criteria. However, sixty-six (76) listed firms met the criteria and were selected and included in the sample of this study

\section{Sources of Data}

The researcher adopted secondary source of data, the annual published financial statements of the companies under study and necessary computations there-from.

\section{Method of Data Analyses}

The statistical technique employed in analyzing the data is the Regression Analysis with the aid of Linear Structural Relations (LISREL) 8.80 while the Statistical Package for Social Sciences (SPSS) Version 25.0 was used for the preliminary analysis. Regression model was adopted for this study to explain variation in the value of dependent variable on the basis of changes in the independent variables. The assumption is that; the dependent variable is a linear function of the independent variable. The analysis will be guided by the specified model in each hypothesis.

\section{Model Specification}

The model used for this study was the researcher's conception. It was neither adopted nor adapted.

Mathematically; $\mathrm{CP}=\mathrm{f}$ (STDC, INS) ie corporate performance is a function of staff training and development cost and also increment in the number of staff

In Stochastic form; $Y=\beta_{0}+\beta_{1} X_{1}+\beta_{2} X_{2}+\mu_{\text {it }}$

The model contains the dependent variable denoted by $\mathrm{Y}$, which represents the dependent variable, profitability $(\mathrm{P})$ and the independent variables $\mathrm{X}_{1}$ and $\mathrm{X}_{2}$ (STDC and NIS) which are components of HRA.

\section{Generally:}

$\mathrm{P}=\beta_{0}+\beta_{1} \mathrm{STDC}_{\mathrm{it}}+\beta_{2} \mathrm{INS}_{\mathrm{it}}+\mu_{\mathrm{it}}$

Specifically:

PROF. $=\beta_{0}+\beta_{1} \mathrm{STDC}_{\mathrm{it}}+\beta_{2} \mathrm{INS}_{\mathrm{it}}+\mu_{\mathrm{it}}$

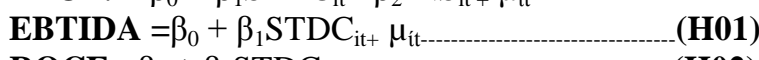

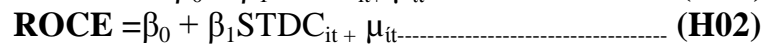

EBTIDA $=\beta_{0}+\beta_{1} \mathrm{INS}_{\mathrm{it}+}+\mu_{\mathrm{it}-\mathrm{\ldots}}$

ROCE $=\beta_{0}+\beta_{1} \mathrm{INS}_{\mathrm{it}}+\mu_{\mathrm{it}--}$ (H04) $\mu_{\text {it }}$ is the error term capturing other explanatory variables not explicitly included in the model.

$\beta_{0}$ is the intercept of the regression.

$\beta_{1}$, are the coefficients of the regression used in determining the significance of the effect of each of the independent or explanatory variables Staff Training and development Cost (STDC) and Increment in number of Staff (INS), on the dependent variable (profitability) measured by, Return On Capital Employed (ROCE) and Earning before tax, interest, depreciation and amortization (EBTIDA)

\section{Hypotheses Testing}

Simple regression analysis was employed in testing and analyzing the hypotheses formulated for this study as earlier stated in chapter one of this project. Simple regression or bivariate regression simply involves predicting a dependent variable from a single predictor (see Pituch\& Stevens, 2016).

Ho $_{1}$ : Staff Training and Development cost has no significant positive effect on Earnings before Taxes Interest Depreciation and Amortization.

\section{Estimated Equations}

EBTIDA_EBI $=-51.791+6.163 *$ STAFFTRA +

Error, $\mathrm{R}^{2}=0.0512$

Standerr (19.412) (0.987)

Z-values $\quad-2.668 \quad 6.243$

P-values $0.008 \quad 0.000$

Error Variance $=146076.550$

From the simple/bivariate analysis output, $\mathrm{R}^{2}=0.0512$ which implies that staff training and development costs account for 5.12 per cent of variations in EBTIDA_EBI. The coefficient $(\beta)=6.163$, z-value $=$ 6.243 while the p-value of 0.000 is well below the 5 per cent margin of error. Based on this we reject the null hypothesis and conclude that Staff Training and Development cost has a significant positive effect on Earnings before Taxes Interest Depreciation and Amortization.

Ho2: Staff Training and Development cost has no significant positive effect on return on capital employed.

\section{Estimated Equations}

ROCE_RET $=13.875-0.293 *$ STAFFTRA + Error, $\mathrm{R}^{2}$ $=0.00298$

Standerr (3.919) $(0.199)$

Z-values $3.540 \quad-1.469$

P-values $0.000 \quad 0.142$

Error Variance $=5955.270$

From the simple/bivariate regression analysis output for Hypothesis $1 b, R^{2}=0.00298$ which implies that staff training and development costs account for only about 
0.3 per cent of variations in return on capital employed (ROC_RET). The coefficient $(\beta)=-0.293$, z-value $=$ 1.469 while the p-value of 0.142 is well above the 5 per cent margin of error. Based on this we accept the null hypothesis 2 and conclude that Staff Training and Development cost has no significant positive effect on returns on capital employed (ROCE_RET).

Ho3:Increment in number of staff has no significant positive effect on Earnings before Taxes Interest

Depreciation and Amortization.

\section{Estimated Equations \\ EBTIDA_EBI $=123.523-37.269 *$ INCREAME + \\ Error, $\mathrm{R}^{2}=0.00360$ \\ Standerr (59.266) (23.076) \\ Z-values $2.084-1.615$ \\ P-values $0.037 \quad 0.106$ \\ Error Variance $=153407.234$}

The regression analysis output for Hypothesis 3 shows that, $\mathrm{R}^{2}=0.00360$ which implies that increases in number of staff account for about 0.36 per cent of variations in Earnings before Taxes Interest Depreciation and Amortization and Return. The coefficient $(\beta)=-37.269$, $z$-value $=-1.615$ while the $p$ value of 0.106 is well above the 5 per cent margin of error. Based on this we accept the null hypothesis $4 \mathrm{a}$ and conclude that increment in number of staff has no significant positive effect on Earnings before Taxes Interest Depreciation and Amortization (EBTIDA_EBI).

Ho4: Increment in number of staff has no significant positive effect on Return on capital employed.

ROCE_RET $=-27.167+14.911 *$ INCREAME +

Error, $\mathrm{R}^{2}=0.0149$

Standerr (11.607) (4.519)

Z-values $\quad-2.341 \quad 3.299$

P-values $\quad 0.019 \quad 0.001$

Error Variance $=5884.351$

The regression analysis output for Hypothesis $4 \mathrm{~b}$ shows that, $\mathrm{R}^{2}=0.0149$ which implies that increases in number of staff account for about 1.5 per cent of variations in return on capital employed. The coefficient $(\beta)=14.911$, $z$-value $=3.299$ while the $p$ value of 0.001 is well below the 5 per cent margin of error. Based on this we reject the null hypothesis 4 and conclude that increment in number of staff has a significant positive effect on Return on capital employed (ROCE_RET).

\section{DISCUSSION OF FINDINGS, CONCLUSION AND RECOMMENDATIONS}

Analysis output of the hypothesis, shows that the coefficient $(\beta)=6.163$, z-value $=6.243$ while the $p$ value of 0.000 is well below the 5 percent margin of error and concluded that Staff Training and Development cost has a significant positive effect on Earnings before Taxes Interest Depreciation and Amortization. This result is in congruence with the results of Amahalu, Agbionu and Obi (2017) whose results revealed that human resource accounting has a positive significant effect on ROA, ROE and ROCE at 5\% significance level. Also Chukwu (2018) revealed that staff training cost, staff development cost and staff salaries significantly affect bank profitability.

Hypothesis 2, shows that coefficient $(\beta)=$ $0.293, \mathrm{z}$-value $=-1.469$ while the $\mathrm{p}$-value of 0.142 is well above the 5 percent margin of error, and concluded that Staff Training and Development cost has no significant positive effect on returns on capital employed (ROCE_RET). This result are in congruence with the results of Udeh (2021) whose result shows that human capital has no significant effect on the earning per shares of the listed firms in Nigeria. Also Ofurum and Adeola(2018) discovered that there is no significant relationship between HRA and the profitability of quoted firm.

Hypothesis 3 shows that, the coefficient $(\beta)=$ $37.269, \mathrm{z}$-value $=-1.615$ while the $\mathrm{p}$-value of 0.106 is well above the 5 per cent margin of error, therefore concluded that increment in number of staff have a negative insignificant effect on Earnings before Taxes Interest Depreciation and Amortization (EBTM_EBI). This is in line with Edom, Inah, and Adanma (2015) whose result showed that there was a significant relationship between training cost, development cost and the profit of the bank. However, the number of staff does not have a significant effect on profit of the bank.

Hypothesis 4 shows coefficient $(\beta)=14.911$, zvalue $=3.299$ while the $p$-value of 0.001 is well below the 5 per cent margin of error. Based on this we reject the null hypothesis 4 and conclude that increment in number of staff has a positive significant effect on Return on capital employed (ROCE_RET), showing that increasing in $1 \%$ leads to Over $14 \%$ increase in financial performance (Return on capital employed). This is in line with the findings of Ezejiofor, JohnAkamelu and Iyidiobi (2017) that increase in staff salary has a positive effect on organizational profitability, also that the level of increment in staff has impact in predicting the profitability of the firm.

The increment in number of staff was found to have a negative insignificant effect on Earnings before Taxes Interest Depreciation and Amortization (EBTIDA_EBI) but has a positive significant effect on Return on capital employed (ROCE_RET)of quoted Nigerian companies. As a result, organizational performance is influenced by the performance of the 
individuals who make up the organization in terms of wage increases, retirement benefits, and the number of employees employed.

From the findings of the study, the following recommendations were highlighted below;

1. Staff Training and Development cost has to be a regular program in the company as this will reduce labour turnover thereby attract more earnings.

2. Increment in number of staff should be a welcomed development of the company's management as this will attract more positive effect on Return on capital employed (ROCE_RET). Companies should therefore expend more on the need to develop and train staff.

\section{REFERENCES}

1. Adebawojo, O.A., Enyi, P.E. and Adebawo, O.O. (2015). Human asset accounting and corporate performance. American Journal of Contemporary Research, 5(1) 46-52. Retrieved from http://www.researchgate.org

2. Adetoun, R.B.,Oluwatobi, O.O., Akinyemi, M. O., and Abeeb, O. M. (2020). Human resource accounting disclosures and financial performance: empirical evidence from manufacturing companies in Nigeria. Lapai International Journal of Management and Social Sciences, 12(2)42-51.

3. Agbiogwu, A.A., Ihendinihu, J.U., and Azubike, J. $U$. (2016). Effects of human resource cost on profitability of banks in Nigeria. Expert Journal of Finance, 4, 10-1

4. Ahangar, R.G. (2011). The Relationship between intellectual capital and financial performance: an empirical investigation in an Iranian company. African Journal of Business Management, 5(1), 88-95. Retrieved from http://ww w.academicjournals.org/ajbm/PDF/pdf2011/4Jan/A hangar.pdf

5. Alekhya, P. and Lakshmi, P. V. (2021). Impact of human resource accounting on companies profitability. Test Engineering and management journal, 83, 16048-16055

6. Amahalu, N., Agbionu, C., and Obi, C. (2017). Effect of human resources accounting on profitability of selected quoted telecommunication firms in Nigeria. Contemporary issues in business management: a multidisciplinary approach. Retrieved from http://www.papers.ssrn.com

7. Amahalu, N., Obi, C., Okika, E., and Abiahu, M. (2016). Effect of human resource accounting on financial performance of quoted Deposit money Banks in Nigeria. Retrieved from https://ssrn.com/abstract $=3050255$

8. American Accounting Association (1973). Committee of accounting for human resources, report of the committee on human resource
accounting.The Accounting Review Supplement to Vol. XLVIII.

9. Appah, E., Tebepah, S.F., and Soreh C.W. (2012). Human resource development mechanism and the performance of public sector accountants' in Nigeria. Current Research Journal of Social Sciences, 4(3), 246-255.

10. Armstrong, $M$ (2006). A handbook of human resource management practice, 10th edition, Amazon retrieved from http://recruitusmc.org/v/pcontent/uploads/2014/10/ Handbook.of. Human Resource Management Practice 10th. Pdf.

11. Aswathappa, K. (2005) "Organizational Behaviour”, Himalaya Publishing House, Mumbai

12. Barney, J.B and Wright, P.M (1997). On becoming a Strategic partner: The role of human resource in giving competitive advantage. Itlaca, Ny: Cornell University, School of Industrial Labour relations, Center for Advanced Human Resource Studies. http://digitalcommons:ilr.comell.edu/cahrsiop/150 4/7/2012

13. Chukwuka, C. (2018). Human resource accounting and the performance of banks: A study of selected quoted banks in Nigeria.Brettonwoods International Journal of Socio-Economic and Financial Studies, 1(1).

14. Edom, G.O., Inah, E. U. and Adanma, E.S. (2015). The impact of human resources accounting on the profitability of a firm: empirical evidence from access bank of Nigeria plc. EuropeanJournal of Accounting, Auditing and Finance Research3(7), 76-94. (www.eaiournals.org)

15. Ekundayo, O.U. and Odhigu, F.(2016). Determinants of human capital accounting in Nigeria. Igbinedion University Journal of Accounting, 1, 103-117.

16. Enyi, P.E. and Adebawojo O.A. (2014). Human resource accounting and decision making in postindustrial economy. American International fro $m$ https://issuu.com/alexanderdecker/docs/impact of human resource accounting.

17. Enofe A.O., Mgbame C., Otuya S. and Ovie C. (2013). Human resources accounting disclosures in Nigeria quoted firms. Research Journal of Finance and Accounting, 4(13).

18. Ezejiofor, R.A., John-Akamelu, R. C. and Iyidiobi, F.C. (2017). Appraisal of Human Resource Accounting on Profitability of Corporate Organization. Economics. Vol. 6, No. 1, 2017, pp. 1-10. doi: 10.11648/j.eco.20170601.11

19. Flamhotz, E.G. and Lcey J.M. (1981). Personnel management, human capital theory, and human resource accounting Los Angels. Los Angeles University Press. Retrieved from http://www.worldcat.org/title/personnelmanagement-human-capital-theory-and-humanresource accounting/oclc/7702347

20. Ofurum, C.O, and Adeola, S. O. (2018). Human resource accounting and profitability of quoted 
firms in Nigeria. International Journal of Advanced Academic Research \& Economic Development, 4 (2).

21. Omodero, C. O. and Ihendinihu, J.U. (2017). Human resource accounting and financial performance of firms in Nigeria: Evidence from Selected listed firms on the Nigerian Stock Exchange. International Journal of Interdisciplinary Research Methods, 4(2)25-33.

22. Pallant, J. (2016). SPSS Survival Manual 5th Edition. Berkshire, England: Open University Press.

23. Pituch, K. A. \& Stevens, J. P. (2016). Applied Multivariate Statistics for the Social Sciences:

24. Analysis with SAS and IBM's SPSS. Sixth Edition. London: Routledge, Taylor and Francis Group

25. Robbins, S. P. (2001). Organizational behavior. Prentice Hall, 9th edition.

26. Rogers and Wright (1998). Measuring organizational performance in strategic human resources management: Looking beyond the Lamppost. CAHRS Working Paper 24-98. Retrieved from

http://www.digitalcommons.ilr.cornell.edu/cahrswp 1135

27. Selvam, M., (2016). Determinants of firm performance: a subjective model. International Journal of Social Science Studies, 4(7).

28. Syed, A.M., (2009). Human resource accounting discloser of Bangladesh companies and its associations with corporate characteristics.BRAC University Journal, 1, 35-43.

29. Tabachnick, B. G. \&Fidell, L. S. (2019). Using Multivariate Statistics, 7th Edition. New York:

30. Pearson Higher Education. Online Edition

31. Wikipedia (2018). Human resources accounting. Retrieved fromhttp://www.en.m.wikipedia.org 